\title{
Web Enabled Multi-Layer Geo-Database for Moinabad Mandal in Rangareddy District, Telangana
}

\author{
Simhachalam Alajangi, Satyanarayana Prasad Nerella \\ National Institute of Rural Development \& Panchayati Raj, North Eastern Regional Centre, Guwahati, India \\ Email: chalamnird@gmail.com, prasad.nsr10@gmail.com
}

Received 18 September 2014; revised 15 October 2014; accepted 10 November 2014

Copyright @ 2014 by authors and Scientific Research Publishing Inc.

This work is licensed under the Creative Commons Attribution International License (CC BY).

http://creativecommons.org/licenses/by/4.0/

(c) (i) Open Access

\begin{abstract}
The importance of Web-based GIS applications for government is to analyze the information they produce and to establish their impact on efficiency, effectiveness and transparency. The potential of Remote Sensing and GIS provides cost and time-effective resource database. An attempt was made to develop a Web enabled Geo database for the Moinabad Mandal, Ranga Reddy District, Telangana. Further this database was used to develop a web enabled multi-layer geo database using ArcGIS Server. It enables the users to know the information and take better decisions, better planning in different rural development sectors.
\end{abstract}

\section{Keywords}

Web GIS, Geo Database, Thematic Layers, ArcGIS Server

\section{Introduction}

The geographic information system has been an effective tool for implementation and monitoring of municipal infrastructure. The use of GIS has been in vogue primarily due to the advantage mentioned below:

- $\quad$ Planning of project

- $\quad$ Make better decisions

- Visual analysis

- Improve organizational integration

How to cite this paper: Alajangi, S. and Nerella, S.P. (2014) Web Enabled Multi-Layer Geo-Database for Moinabad Mandal in Rangareddy District, Telangana. Journal of Geographic Information System, 6, 690-705. 
WebGIS is a new technology used for data display and to access analysis and query functionality from a GIS Server over the internet or intranet. Interactivity, user-friendliness and platform independent operation are some of the major advantages of WebGIS.

\subsection{Planning of Project}

Advantage of GIS is often found in detailed planning of project having a large spatial component, where analysis of the problem is a pre requisite at the start of the project. Thematic maps generation is possible on one or more than one base maps, example: the generation of a land use map on the basis of a soil composition, vegetation and topography. The unique combination of certain features facilitates the creation of such thematic maps. With the various modules within GIS it is possible to calculate surface, length, width and distance.

\subsection{Making Decisions}

The adage "better information leads to better decisions" is as true for GIS as it is for other information systems. A GIS, however, is not an automated decision making system but a tool to query, analyze, and map data in support of the decision making process. GIS technology has been used to assist in tasks such as presenting information at planning inquiries, helping resolve territorial disputes, and siting pylons in such a way as to minimize visual intrusion.

\subsection{Improving Organizational Integration}

Many organizations that have implemented a GIS have found that one of its main benefits is improved management of their own organization and resources. Because GIS has the ability to link data sets together by geography, it facilitates interdepartmental information sharing and communication. By creating a shared database one department can benefit from the work of another-data can be collected once and used many times.

\section{Web Based GIS Applications}

Web application is an application that is accessed over a network such as the internet or an intranet (Shklar and Rosen, 2009). Web applications are popular because of the ubiquity of web browsers and the convenience of using a web browser as a client, sometimes called a thin client (Peng and Tsou, 2003). A key reason for their popularity is the ability to update and maintain web applications without distributing and installing software on potentially thousands of client computers and is the inherent support for cross-platform compatibility (Fowler and Stanwick, 2004).

The number of web-based applications that use techniques derived from geographic information system (GIS) have seen an enormous increase (Haklay et al., 2008). Through a web interface, GIS equipped tools can provide a wide range of planning activities. At the same time, they are able to assist the coordination between the planning authorities and public. In the planning processes, these tools, hence, can be a simple map to front-ending complex spatial analysis ranging from day-to-day to future planning which make more effective processes.

To give users' expected results of real time GIS analysis, the proper tool requirements are important with the choice of mapping, database, and development technologies and standards. This further presents an assessment involving different technologies and their value in order to achieve in a range of circumstances (Grunwald et al., 2003). Web-based GIS is a GIS distributed across a computer network to integrate, disseminate, and communicate geographic information on the World Wide Web (WWW) (Peng and Tsou, 2003). Also it provides end-users a cost-saving solution to access up-to-date spatial datasets and information comparing to other GIS systems (Horanont et al., 2002; Painho et al., 2001). Hence, an important part of every web-based GIS application is its mapping or visualization technology, which makes it possible to show data in the form of maps.

\section{Study Area}

Moinabad Mandal, Rangareddy District, Telangana was taken as a project covering 27 villages. The present

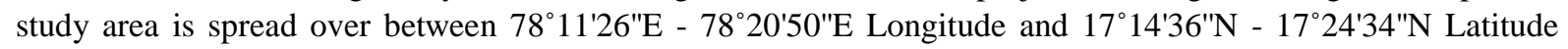
occupying 206 Sq. Km area.The Moinabad Mandal is surrounded by Rajendra Nagar, Shankarpalli, Chevella, Shabad and Shamshabad Mandals. The study area map is shown in Scheme 1. 


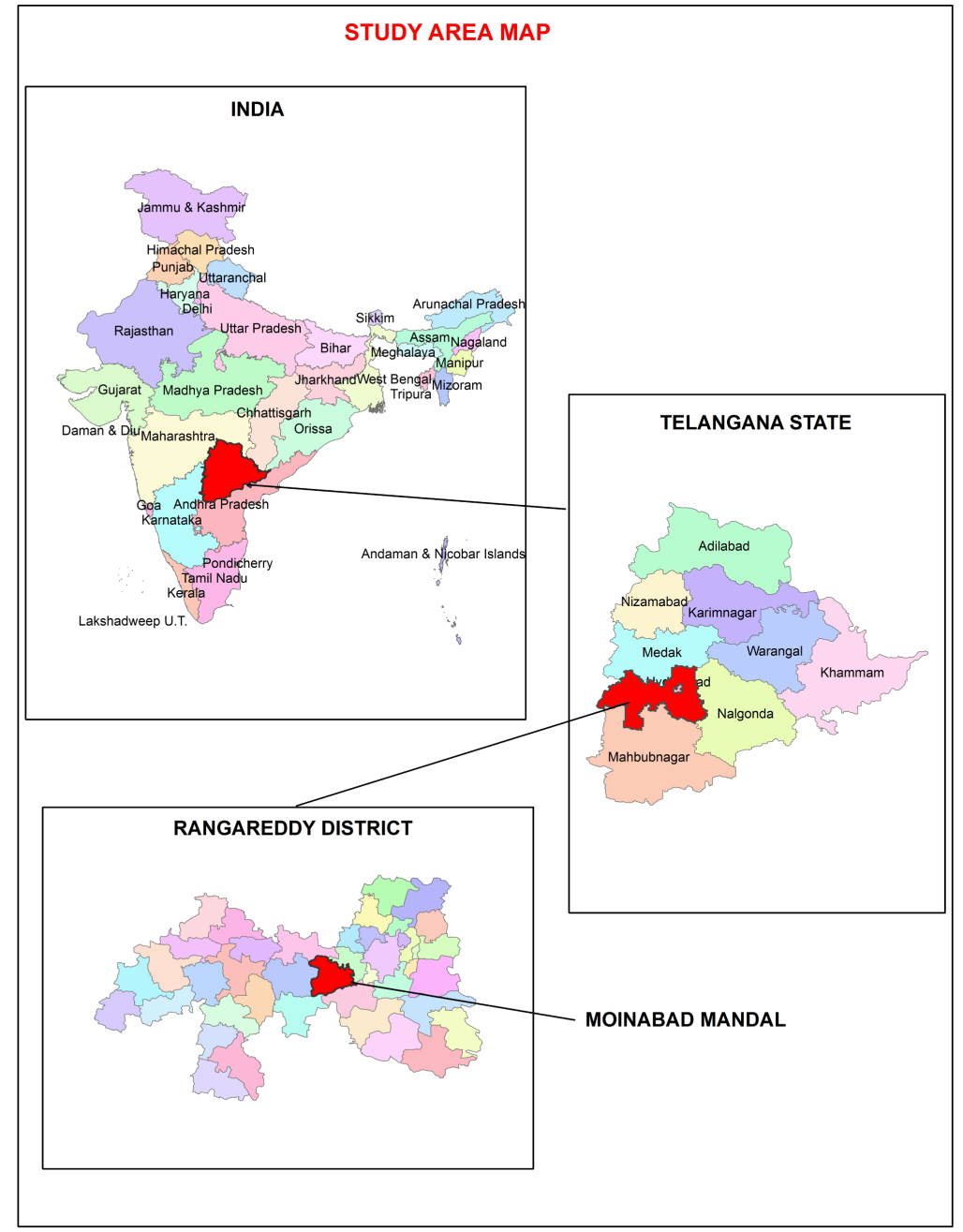

Scheme 1. Study area map.

\subsection{Transport and Communication}

The study area Moinabad Mandal is well connected by road network. The National High-ways passing through the District and other major roads maintained by different agencies i.e. under state highway $260 \mathrm{Kms}$, Major District roads 1160 Kms, and Panchayathi Raj 4370 Kms. account for 5790 KMs. of total road length.

\subsection{Climate}

The Climate of the Block is characterized by a hot summer and is generally dry except during the South west monsoon season. The year may be divided into four seasons. March to May is the summer season, June to September constitutes the South West monsoon season, October to December from the North East monsoon season and January to February is the winter season.

\subsection{Temperature}

From about mid-February, both the day and night temperatures begin to increase steadily. May is the hottest month with the mean daily maximum temperature at $39.6^{\circ} \mathrm{C}$ with the onset of the southwest monsoon into the district early in June, there is an appreciable drop in temperatures and weather becomes more pleasant. In the beginning of November, the decrease in both day and night temperature is rapid. December is the coldest month with the mean daily maximum temperature at $28.6^{\circ} \mathrm{C}$ and mean daily minimum temperature at $13.6^{\circ} \mathrm{C}$. 


\subsection{Rainfall}

The district has a normal rainfall of $781.0 \mathrm{~mm}$. The bulk of it is received through the South West monsoon during the period from June to September. The detailed analysis of precipitation is very important in the assessment, management and development of Land and water resources.

\section{Review of Literature}

The existing literature on Application of GIS in Planning Rural Development and Web enabled GIS information systems in different places are reviewed as fallows.

Dr. K. M. Lakshmana Rao [1], Head, Centre for Transportation Engineering, IPGSR, Jawaharlal Nehru Technological University, (2003) have been discussed about Rural Infrastructure Planning with emphasis on road network connectivity by Coplanar Concurrent Theory. Rural roads are an important sector in rural development, which deals in all aspects of development including agriculture, health, education, forestry, fisheries, small-scale industries, trade, commerce etc. that depends on good communication. Rural transportation network will give shape to the living environment of villagers; rather roads of rural transportation are the connectivity elements in our society. Appropriate combination of various links both technically and economically can generate rural traffic infrastructure, which should be prepared for the measure of land development.

\subsection{Bhuvan: Web Geoportal for Indian Earth Observation Data}

Bhuvan is an initiative to showcase Indian imaging capabilities with focus on Indian region, including global coverage. It is an ambitious project of ISRO to take Indian images to other value added services in multiple spatial resolutions to the people through a web geoportal for easy access to information on basic natural resources in the geospatial domain.

\section{2. e-MANCHITRA-Dr. L. R. Yadav}

The project aims at eliminating the inter-regional disparities that persist as a problem in the decentralization process, by generating village, block, district, divisional and state level thematic atlases based on SPIDER indicators. Which gives greater responsibility and power to the local bodies for effective implementation and monitoring of development programmes. This helps in reducing the time lag, increases the consistency and accuracy of data, cost efficiency and transparency, thus facilitating the superimposition of different layers on the same administrative unit.

\subsection{Infrastructures Planning}

Infrastructures Planning in Rural Massachusetts has been discussed by Jeanne H. Armstrong, Meir Gross, John R. Mullin and Robert D. Yaro (2006) [2], This paper presents the results of a study of rural infrastructure problems in Massachusetts. While the laboratory was one State in the U.S.A., the results are applicable to situations in mature regions of many developed countries, where tight budgets and decaying infrastructure often go hand in hand. To us, infrastructure means the system of roads, sewers, water lines, electrical lines and structures that are under municipal control.

\subsection{An Approach for Planning Rural Road Connectivity to Habitations under PMGSY}

An Approach for Planning Rural Road Connectivity to Habitations under PMGSY has been discussed by Vivek Chitale and M. Vinayak Rao (2006) [3] Electronic governance includes all aspects of physical planning, management of social and physical infrastructure, and enhancement/restructuring of existing facilities, facility management and land use planning. In all these areas, there is a special emphasis on spatial dimensions. In the present age of emerging technologies, Geomatics which is the synergy of multiple disciplines has evolved as a separate discipline dealing with spatial and non-spatial information, its method of acquisition, organization, classification, analysis, management, display and dissemination

\subsection{GIS Based Modeling for Rural Infrastructure Planning}

GIS Based Modeling for Rural Infrastructure Planning has been altercated by Dr. S. K. Ghosh [4], Asso- 
ciate Professor of Civil Engineering, Indian Institute of Technology (2004) funded by Department of Science \& Technology New Delhi, a strategic GIS based model for rural infrastructure planning has been developed. Laksar block of Haridwar district in Uttaranchal has been selected for developing the prototype model.

\subsection{A Web-Based Application for Real-Time GIS}

A Web-Based Application for Real-Time GIS: by O. Ozdilek, a, *, D. Z. Seker, ITU, Civil Engineering Faculty, Maslak Istanbul, Turkey. As weather is the statement of the physical conditions at an instant, forecasting is of concern to one and all living bodies over the earth. As such, time immemorial weather forecasting is a subject of great concern for the physical scientists (Saseendran, 2003).

\subsection{Web-Based GIS and Spatial Decision Support System Watershed Management}

Jin-Yong Choi, Bernard A. Engel and Richard L. Farnsworth. This paper explores relationships between information technology and hydrologic/water quality analysis DSS. It also describes a conceptual web-based SDSS framework in terms of system components. Further, a web-based watershed management SDSS that has been operating based on this framework using web-GIS for watershed delineation, map interfaces and data preparation, a hydrologic model for hydrologic/water quality impact analysis and web interface programs foroperation through the Internet.

\section{Data Used and System Design}

Toposheets: 56K3NE, 56K7/NW, 56K3SE, 56K7SW, 56K4NE, 56K8NW

Satellite data: Quick bird Image (Bing Map), IRS P6 LISS IV and PAN data

Ancillary Data and Field Data

The following methodology has been adopted to generate the multi-layer geo database.

\subsection{Maps Preparation}

Different thematic maps namely base map, land use/land cover, slope, aspect, geology, geomorphology, hydro-geomorphology, ground water potential and soils were prepared based on the standard methodology defined by National Remote Sensing Agency, Dept. of Space, Govt. of India as per IMSD guidelines.

\subsection{Base Map}

The Base map was prepared from Survey of India toposheets on 1:25,000 scale comprising drainage system, settlements, village administrative boundaries and road network for the study area. The toposheets used in the study area are 56K3NE, 56K3SE, 56K4NE, 56K7NW, 56K7SW and 56K8NW.

\subsection{Existing Infrastructure Facilities Mapping}

All the facilities are mapped with Handheld Trimble Juno SB GPS.

\subsubsection{Transport Facilities}

As major area of Moinabad Mandal was moderately well in population, most of them are having BT Road, Cart-Track and Footpath. The transport facilities map is showing in Figure 1.

\subsubsection{Education Facilities}

As a rural area, the Moinabad Mandal has having temperate educational facilities, but for this area it is good to have this much location of educational facilities such as primary schools, secondary schools and middle schools. Moinabad Mandal has 23 primary schools, 14 middle Schools and 5 secondary (High school). There is only one college in Moinabad Mandal. The educational facilities map is showing in Figure 2.

\subsubsection{Medical Facilities}

Medical facilities in Moinabad Mandal are reasonable, as it is a rural area. Moinabad Mandal has only 1 Primary Health Center, 10, Primary Health Sub Center, 3 Allopathic Center, 1 Ayurvedic Center, 1 Unani Center, 1 
Homeopathic Center, 2 Health Center and 1 Nursing Home.

\subsubsection{Post Offices}

Moinabad Mandal also contains other facilities such as post offices. It has 11 post Offices, 1 Telegram office.

\subsection{Drainage Network Map}

A drainage basin is a natural unit draining run-off water to a common point. The drainage map consists of all water bodies, rivers, tributaries, perennial \& ephemeral streams, reservoirs, tanks, ponds and the entire drainage network from first order originating in the area to the last order joining the rivers, tributaries and tanks based on topography. Drainage network helps in delineation of watersheds. Drainage density and type of drainage gives information related to runoff, infiltration relief and permeability.

The drainage map is prepared using projected toposheets of Survey of India in 1:25,000 scale and updated

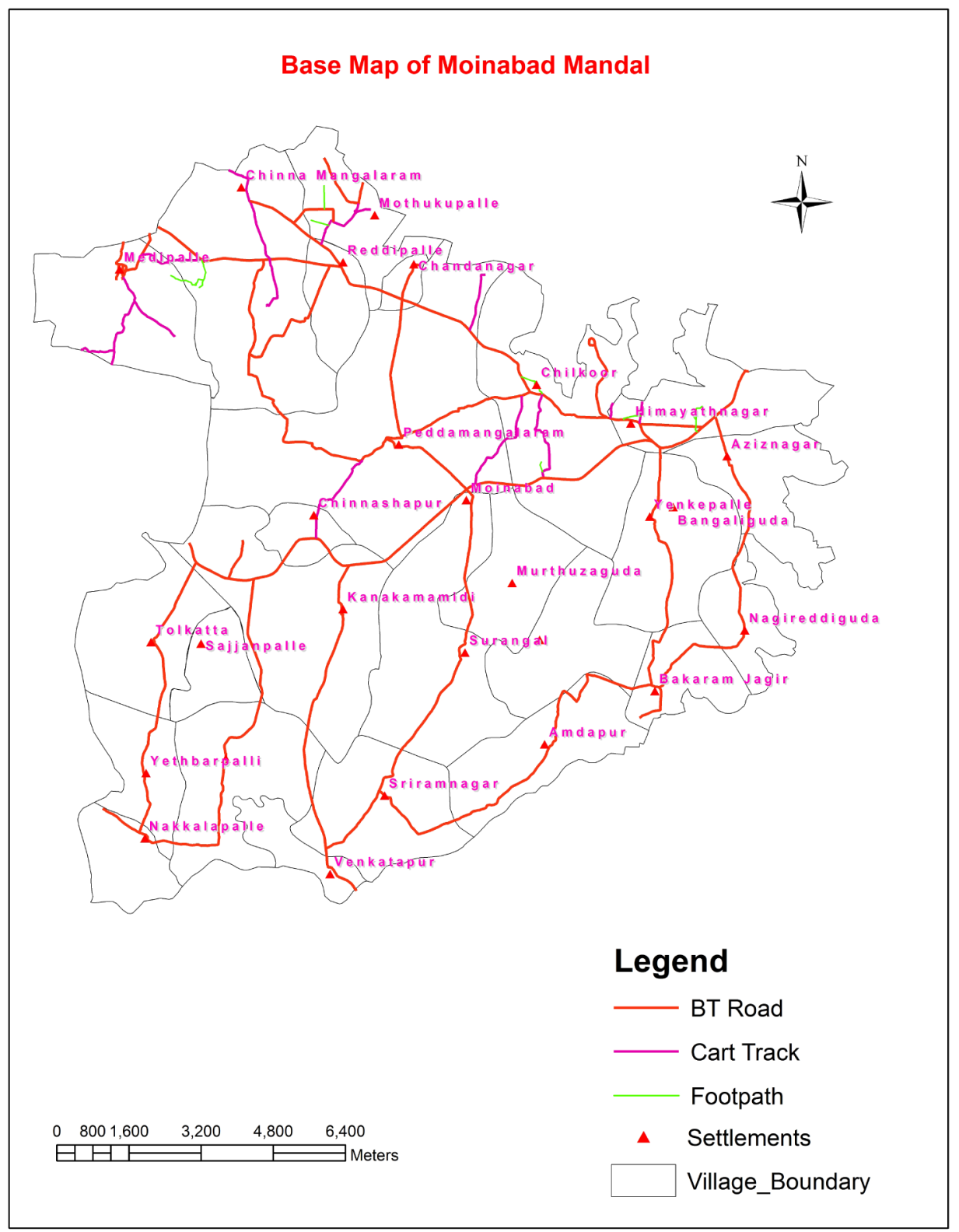

Figure 1. Base map. 


\section{Educational Facilities Map of Moinabad Mandal}

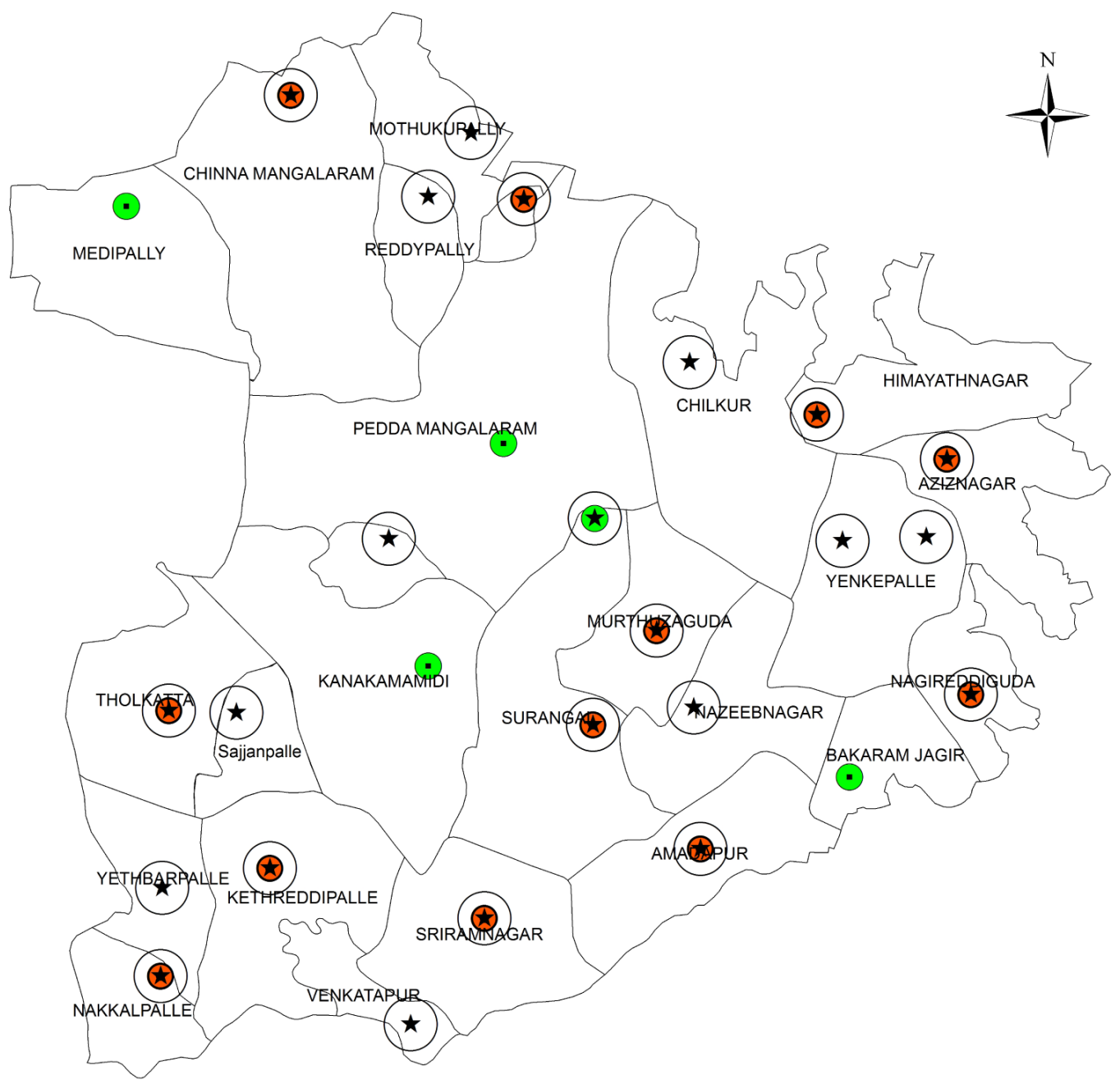

Legend

Æ Existing_Primary_Schools

- Existing_Upper_Primary_School

○ Existing_HighSchools

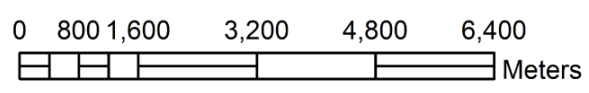

Figure 2. Educational facilities map.

using latest satellite data wherever deviations and new developments are observed. Based on the post monsoon satellite image extent of water spread and dry parts are updated. The water bodies which did not exist at the time 
of survey of toposheets, if any are also captured based on satellite imagery. The drainage map is showing in Figure 3.

\subsection{Generation of TIN (Triangulated Irregular Network) \& DEM (Digital Elevation Model)}

First contour data was digitized from projected toposheets with an interval of $5 \mathrm{mts}$. Contours are imaginary

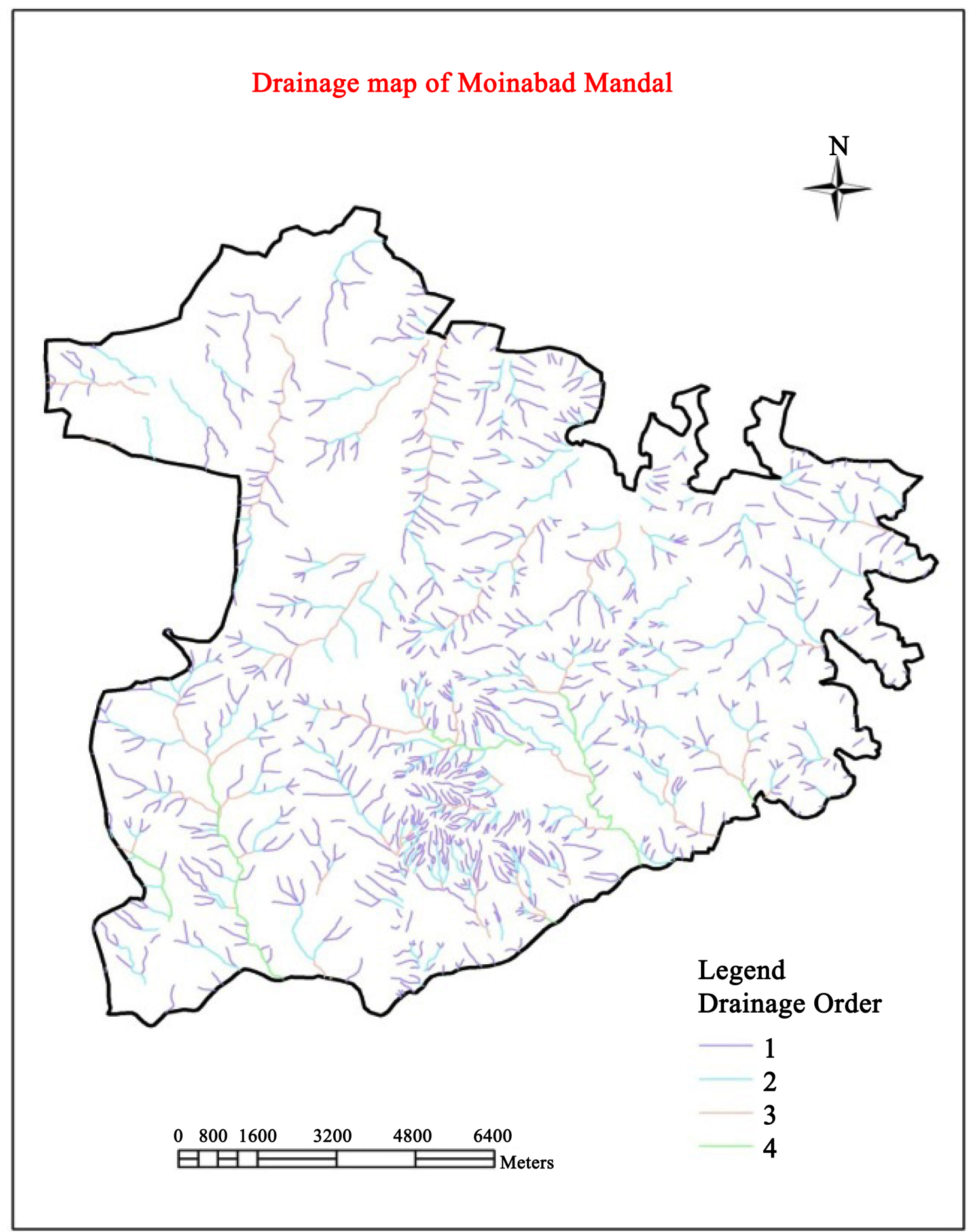

Figure 3. Drainage map. 
lines drawn on map connecting points of equal heights. These are represents the elevation or height of the land surface. The lowest contour was $535 \mathrm{~m}$ and the highest contour was 630 in the study area.

TINs are one of three formats commonly used to represent functional surfaces. The TIN data structure minimizes the number of points needed to accurately represent surface variations. TINs can be represented directly as contours, either alone or in combination with nodes, edges, and/or triangles. The standard attributes calculated for TIN.

For the generation of the TIN, contour data in the vector format was used to generate TIN using ArcMap 3D analyst functions. Later this TIN is converted to DEM (Elevation raster) raster form by using spatial analyst functions. Surface analysis process involves creation of elevation surfaces such as Digital Elevation Model (DEM) from elevation data available either in the form of spot heights or contours.

\subsection{Slope and Aspect Map}

Slope is the degree of inclination of the surface from horizontal expressed in percent or degrees. In survey of India Toposheet the heights shown by contours (lines of equal elevation), which also give an indication of the general topography and relief.

The slope information is useful in understanding the topography soil types their erodability, surface drainage. Slope and relief also plays an important role in designing various check dams, canal alignments and transportation planning. Slope is a vital for land capability assessment, formulation and water conservation measure.

It is important to note that when the slope angle equals to 45 degrees the rise and run are equal and the slope angle is equal to $100 \%$. The slope map thus generated from elevation raster exhibits different slope categories depending up on the slope of the terrain. The output cell size plays a very important role in generating output slope raster. Slope map can be prepared manually as per AIS \& LUS (All India Soil and Land Use Survey) and also by using "Slope” option under Surface analysis function in Arc Map.

These slope classes can be reclassified as per our requirement. In general slope map comprises of seven broad classes as per AIS \& LUS (All India Soil and Land Use Survey). The slope map was prepared using The DEM was used as a base for the generation of slope classes. The maximum slope was observed in the study area is below $5 \%$.

\subsection{Aspect}

Aspect is the direction of slope with respect to north. In output slope raster generation, aspect identifies the down-slope direction from each cell to neighboring cells. The aspect values of the output raster will be measured in the compass direction. i.e. from N-NE-E-SE-S-SW-W-NW ( i.e. $0^{\circ}-360^{\circ}$ in clock-wise direction). Similarly, flat surfaces which do not possess any direction can also be depicted.

\subsection{Land Use/Land Cover Map}

Land use is a primary indicator of the extent and degree to which man has made an impression on the earth's landscape. In one sense, it is an account of impact that man has made on the ecology, the growth and relevance of the ancient civilization. Wherever agricultural resource management is positive in consonance with the contemporary and future needs of mankind, civilization has flourished. In the pastoral age, land use was developed and modified over centuries when man tried to create a particular environment suited to his requirement. The LULC map is showing in Figure 4.

\section{Visual Interpretation}

Image interpretation processes is an act of examining images/photographs for the purpose of identifying objects and judging their significance. A systematic study of satellite images usually involves two basic visuals i.e. Image elements and terrain elements.

Following are the eight characteristic Image elements that aid in image interpretation.

i) Tone/Colour, ii) Texture, iii) Pattern, iv) Shape, v) Size, vi) Shadows, vii) Site, viii) Association Terrain Elements.

In addition to the image elements described above, the terrain elements listed below are also highly useful for image interpretation. They are (i) Drainage patterns, (ii) Drainage texture, (iii) Topography/landform, (iv) Erosion status. 


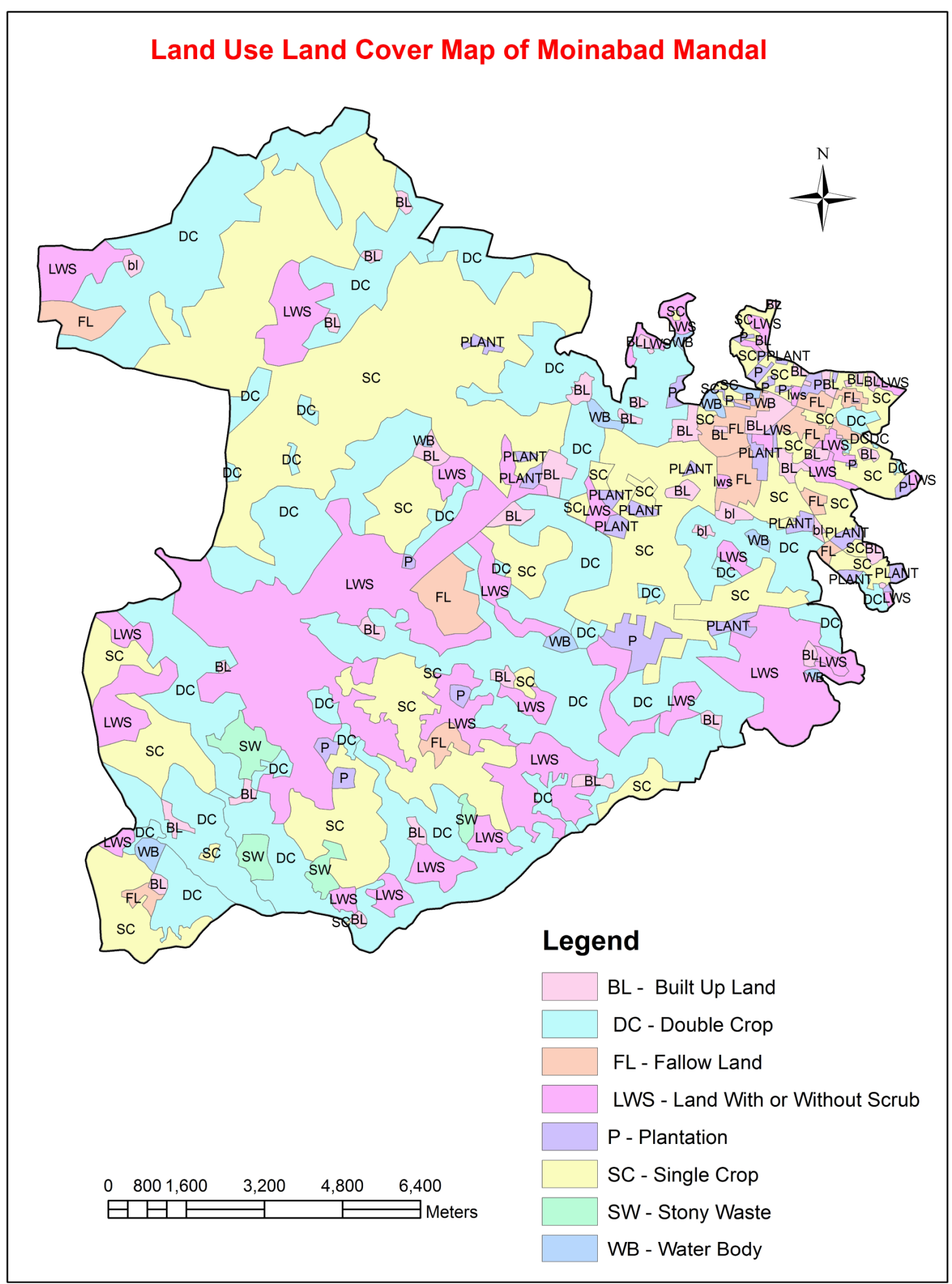

Figure 4. Land Use/Land cover map.

The land use/land cover categories of the Mandal have been grouped into Six Level-I classes Viz., built-up area, agricultural lands, forest lands, wastelands, water bodies and others. These Level-I classes have been further 
sub-divided into 11 Level-II classes. A detailed description of each of the land use/land cover class is described in the following sub sections.

\subsection{Built-Up Land}

These are the areas of human habitation developed due to intensive non-agricultural use. The major villages in the Moinabad Mandal are Moinabad, Pedda mangalaram, Aziznagar other villages. Chilukuru is the holy place in the study area. The settlements cover an area of 606.59 hectares.

\subsection{Crop Land}

These lands are primarily used for production of food, fiber, commercial and horticultural crops. This category is by and large is dependent on agro-climatic conditions and it is the dominant category in the study area. The total crop land in the Moinabad Mandal is 6982.96 ha and double crop area is 7051.8 ha.

\subsection{Fallow Land}

These are the agricultural lands temporarily allowed to rest un-cropped during the agricultural year. This category could be delineated using temporal satellite data wherein the signature of crops in the cropped areas is conspicuous by their absence as on the data of satellite overpass. There may be various reasons that may be attributed for keeping the land fallow-like social, economic and natural factors. This category occurs as small isolated pockets within crop land and covers an area of 654.16 ha.

\subsection{Plantations}

It is described as an area under agricultural tree crops, planted adopting certain agricultural management techniques. These plantations covers an area of 464.76 ha of Moinabad Mandal.

\subsection{Wastelands}

It is described as degraded land which can be brought under vegetative cover with reasonable effort and which is currently under-utilized and land which is deteriorating for lack of appropriate water and soil management or on account of natural causes (NRSA. 1991). Three categories of wasteland have been identified and mapped in the study area. A brief description of which is given below.

\subsection{Land with/without Scrub}

The land with scrub are the lands with soils that are too shallow; skeletal or chemically degraded lands with moderate to steep slope and are mostly covered with scrubs of different densities and varying height. Land without scrub is the counter part of the previous category, but without any vegetation cover on the land. The total area under this category is 4152 ha.

Stony waste area covers 238.3 ha.

\subsection{Water Bodies}

The streams/rivers, tanks, and reservoirs are included in this category. The major stream passing through the Mandal is Machkund. These are being used for irrigation and drinking purposes. Water bodies cover an estimated area of 133 ha.

\subsection{Geology}

The most of the study area are covered with Deccan traps and some portion covered with granitic gneisses. The GSI (Geological Survey of India) geological map on 250,000 was used as base and updated with latest satellite imagery for the preparation of Geology map.

\subsection{Structural Map}

The weak zones such as faults, thrusts, shere zones, fractures etc., and linear intrusions such as dykes, quartz 
viens, etc., form the structure controlled units. Irrespective of rock type and land form, they act as conduits and barriers for ground water movement. The structural map of moinabad mandal shows the only lineaments.

\subsection{Geomorphology}

Geomorphology is the study of forms and process of landforms, which are the products of various exogenetic and endogenetic forces. The synoptic view of satellite imagery facilitates better appreciation of Geomorphology and helps in mapping of different landforms and their assemblage. The photo-interpretation criteria, such as tone, texture, shape, size, location, association, physiography, genesis of the landforms, nature of rocks/sediments, associated geological structures, etc. are to be used for identification of different landforms/geomorphic units. Lithology, drainage and contour maps are considered while preparing the geomorphology map.

For the present study area IRS P6 LISS-IV July 2010 satellite imagery and SOI Toposheets 1:25,000 scales have been used to map various geomorphic features in order to delineate groundwater potential zones in the area. Based on the interpretation of the satellite imagery and SOI Toposheets the following hydro-geomorphic units have been delineated on 1:25,000 scale.

The geomorphic units occurred in the study area are described Moderately Dissected plateau (MDP) unit is mostly seen in the central part of area covering 1229 ha. and the groundwater prospects in this unit are poor to moderate. Moderately thick lateritic plateau (MLP) mapping unit occupies an area of 341 ha of the total study area. Structural valley (SV) unit is mostly seen along the major streams in the study area covering an area about 382 ha.

\subsection{Ground Water Prospects Map}

Groundwater is the only reliable source for irrigation in the study area. The area experience recurrent drought conditions and acute shortage of even for drinking purpose. Shallow dug wells, which tap weathered zone, with transmissivity, but they are limited in number. The groundwater prospects in the moderately dissected plateau in the study area are poor to moderate.

Ground water prospects based on the integration of the thematic layers [5] namely, lithology, geological structures, geomorphic units and ground water recharge conditions final ground water prospects map has been prepared indicating the ground water potential zones in the study area. The integration of the thematic layers for Ground water prospects shown in Table 1.

In this present study area covers the 382 ha in moderate to good, 341 ha in moderate and 1231 ha in poor to moderate unit occupies an area of the study area.

\subsection{Soil}

Soil is a major component of land system which provides a medium for plant growth. The potentials and limitations of a soil for sustained use under agriculture, horticulture, silvipasture and forestry as well as its response to irrigation and other management practices are controlled by its inherent qualities and characteristics. The quality of the soil is a function of its morphological, morphometric, physical and chemical characteristics. These characteristics are expressed a taxonomic class as depicted on soil map with locational reference. Soil mapping of the region is intended to serve as a crucial input for preparing an integrated plan for sustainable development of the area. Soil surveys provide desired information on nature, location, extent and physio-chemical characteristics along with their spatial distribution.

The specific objectives of the soil mapping are Identification, characterization and classification of the soils of the area, Generation of derivative maps and Land evaluation for food/cash and horticultural crops.

Soil map is showing distribution of soil types and/or soil properties (soil $\mathrm{pH}$, textures, organic matter, depths of horizons etc.) in the area of interest. It is typically the end result of a soil survey inventory, i.e. soil survey. Soil maps are most commonly used for land evaluation, spatial planning, agricultural extension, environmental protection and similar projects. Traditional soil maps typically show only general distribution of soils, accompanied by the soil survey report. Many new soil maps are derived using digital soil mapping techniques. Such maps are typically richer in context and show higher spatial detail than the traditional soil maps. Soil maps produced using (geo) statistical techniques also include an estimate of the model uncertainty. In the study area, Red Loamy soils predominate with coverage of $67 \%$ of the villages of the Mandal. The Soils are poor textured and 
easily drained. Sandy loamy soils come next with 33\% of the villages of the Mandal. The soil map is showing in Figure 5.

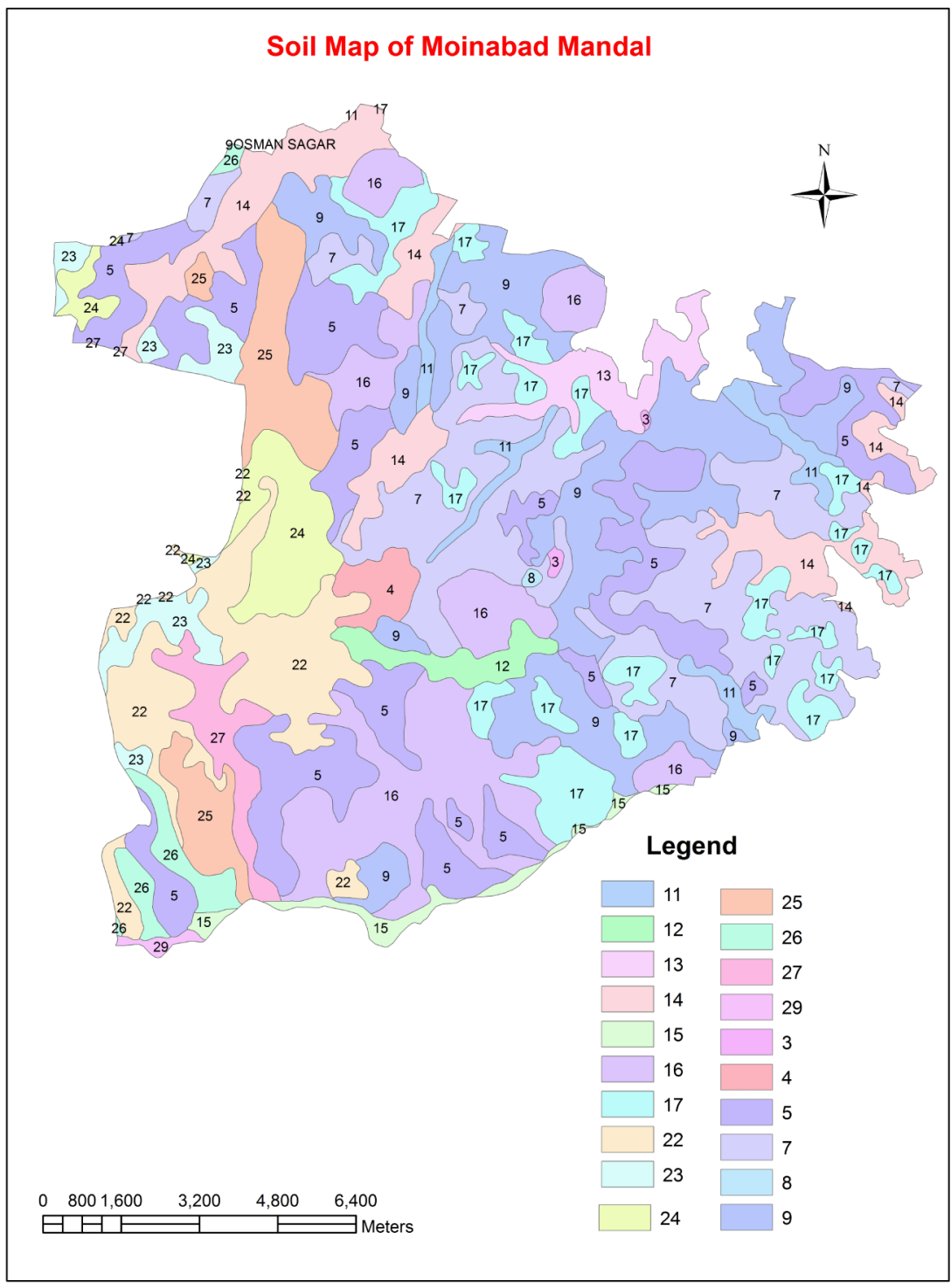

Figure 5. Soil map.

Table 1. Ground water prospects.

\begin{tabular}{|c|c|c|c|c|c|}
\hline $\begin{array}{l}\text { Mapping } \\
\text { Symbol }\end{array}$ & $\begin{array}{l}\text { Hydro geomorphic } \\
\text { Units }\end{array}$ & Litho-Stratigraphy & Structure & Description & Ground water prospects \\
\hline SV & Structural valley & Basalts & $\begin{array}{l}\text { Associated } \\
\text { with } \\
\text { Fractures/ } \\
\text { Lineaments }\end{array}$ & $\begin{array}{l}\text { The valley portions of basalts } \\
\text { weathered to a considerable depth } \\
\text { and associated with fractures/ } \\
\text { lineaments. }\end{array}$ & $\begin{array}{l}\text { Moderate to good. Good yields } \\
\text { are expected along } \\
\text { Fractures/Lineaments. }\end{array}$ \\
\hline MDP & $\begin{array}{c}\text { Moderately } \\
\text { dissected plateau }\end{array}$ & Basalts & -do- & $\begin{array}{l}\text { Shallow valleys/Gullies with gentle } \\
\text { sloping land developed due to } \\
\text { stream erosion on plateau. }\end{array}$ & Poor to moderate. \\
\hline MLP & $\begin{array}{l}\text { Moderately thick } \\
\text { lateritic plateau }\end{array}$ & $\begin{array}{c}\text { Laterites as capping } \\
\text { over basalts }\end{array}$ & -do- & $\begin{array}{l}\text { Elevated flat land with } \\
\text { moderately thick lateritic } \\
\text { Plateau. }\end{array}$ & $\begin{array}{l}\text { Moderate. Ground water occurs } \\
\text { mainly in the weathered and } \\
\text { fractured zones of basalts. }\end{array}$ \\
\hline
\end{tabular}




\subsection{Land Capability Classification}

The knowledge of land capability classification is prerequisite and important for planning, implementation \& execution of the work of soil and water conservation programmes. Land capability classification is a systematic classification of different kinds of land according to those properties which determine the ability of the land toproduce common cultivated crops \& pasture plants virtually on permanent basis (Tejwani, 1976). This classification is made primarily for agricultural purposes and it enables the farmer to use the land according to its capability and to treat it according to its need. The concept of land capability classification has been developed in USA for soil conservation on farmlands.

\subsubsection{Land Capability Classification Scheme}

The land is divided into eight capability classes, which are numbered in Roman numerals from I to VIII. Each class assigned a standard Colour. These eight classes are grouped in two Land use suitability groups viz., (i) "Land suited for cultivation and other uses" (class I to Class IV), and (ii) "Land not suited for cultivation, but suitable for other uses" (Class V to Class VIII). The land capability classes are based on the degree of erosion hazards and the intensity of limitations for use. Class I land is the best and the most easily farmed land and has no hazard or limitation for use, while in class VIII land nothing of economic value can be produced, and it may need protection \& management to conserve other more valuable lands and watersheds.

\subsubsection{Land Capability Subclasses}

Land capability subclasses represent the dominant limitation for agricultural use. Class I soils do not have limitations for crop production and are not assigned a subclass.

Sub class e is made up of soils for which the susceptibility to erosion is the dominant problem or hazard affecting their use. Erosion susceptibility and past erosion damage are the major soil factors that affect soils in this subclass.

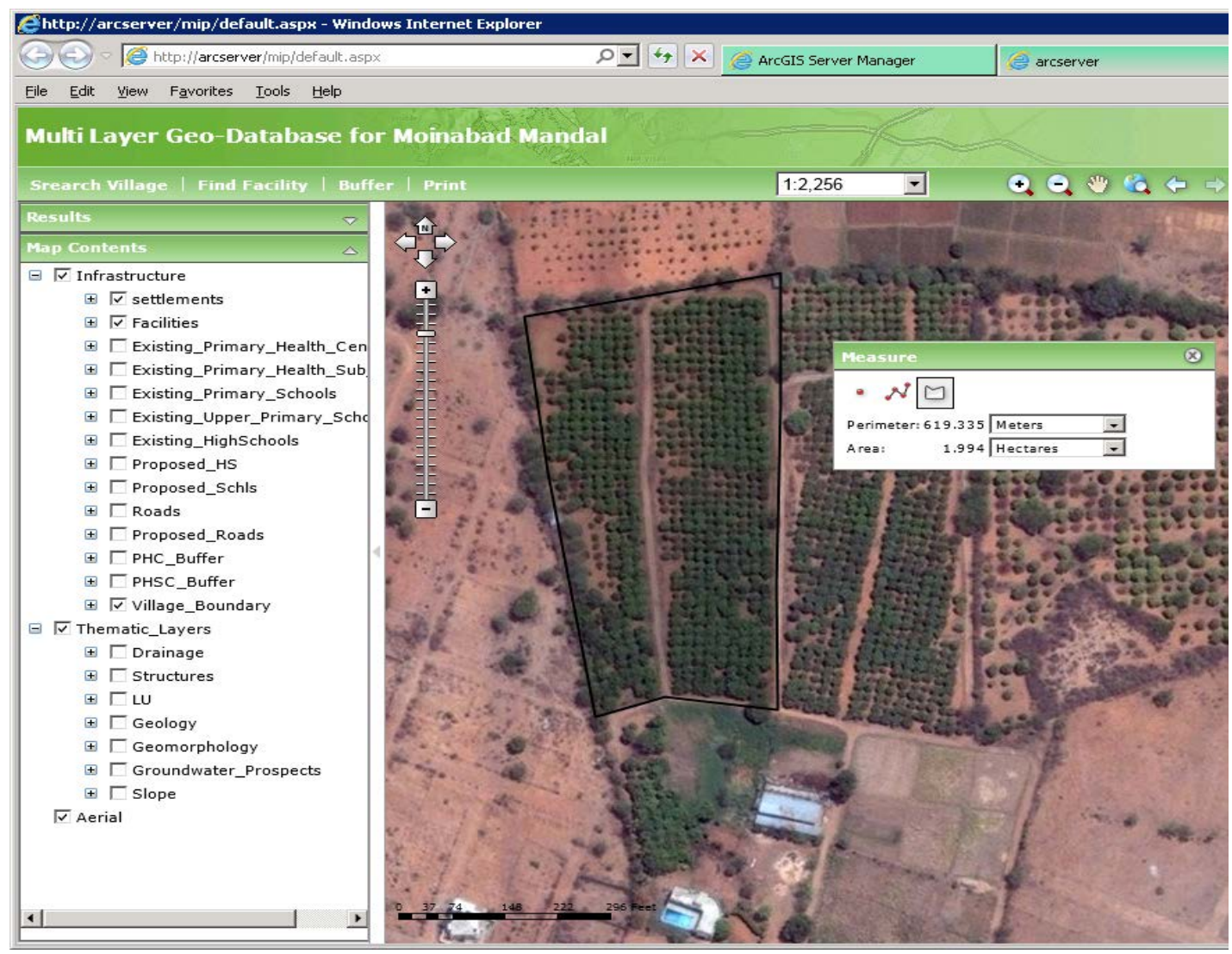

Figure 6. Calculating area. 


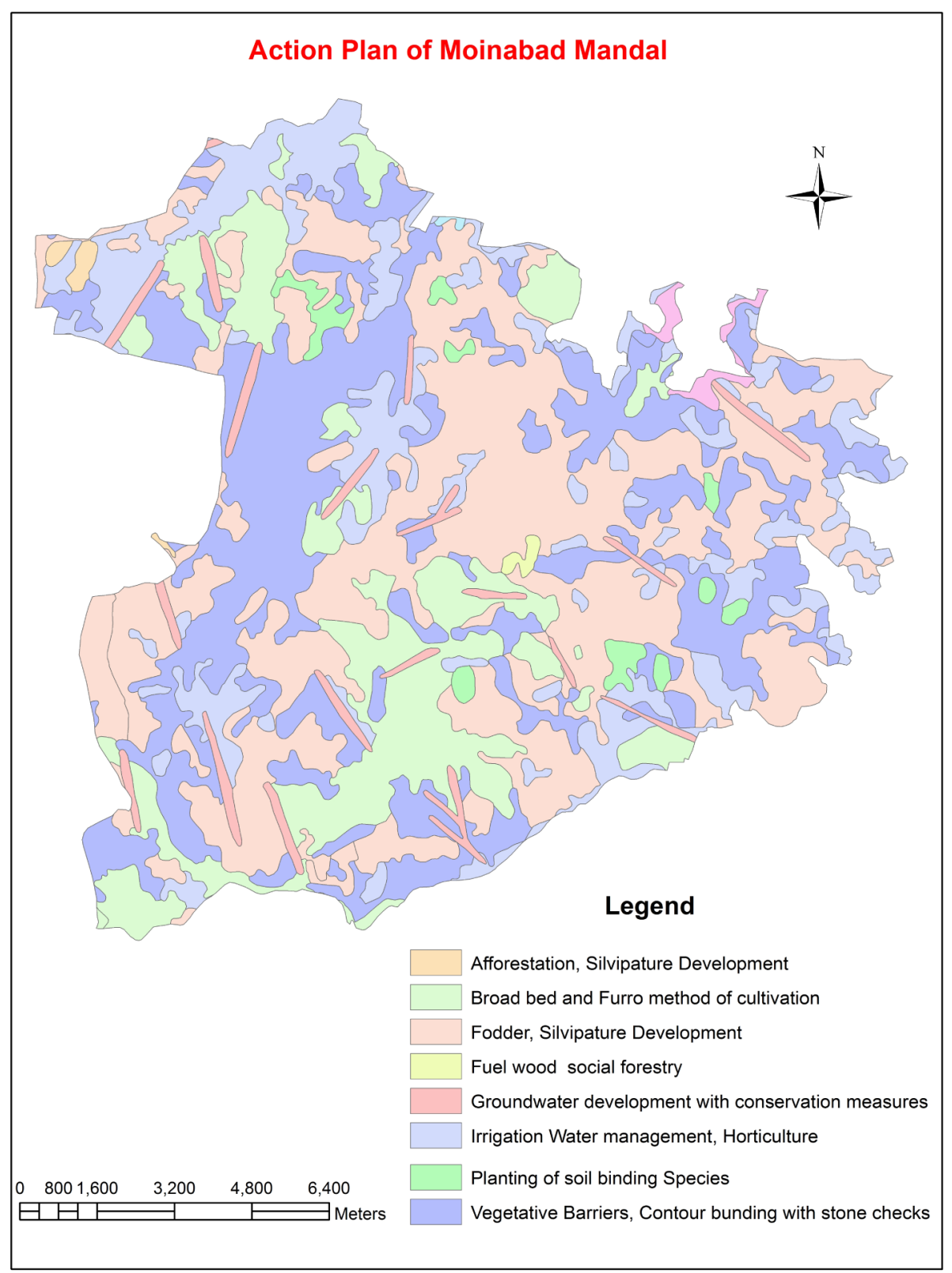

Figure 7. Action plan map.

\subsection{Land Irrigability Classification}

The interpretation of soil and land conditions for irrigation is concerned primarily with predicting the behavior of soils under the greatly altered water regime brought about by irrigation. To carryout land irrigability classification of command areas, special interpretation and classification of soils for sustained use under irrigation are often required. The classification is based on effective soil depth, soil texture, soil permeability, coarse fragments etc. The soils are grouped into soil irritability classes according to their limitations for sustained use under irrigation, regardless of their location or the size of the individual mapping unit.

\section{Land Irrigability Classes}

The suitability of land for irrigation depends on physical, economic and cultural factors in addition to soil irrigability classes. Besides, the following physical and socio-economic factors are considered in determining land irrigability classes. 
- Quality and quantity of irrigation water available from surface and ground water resources.

- Requirement of drainage.

- Cost of production of crops and their yield potentials.

- Costs of land development.

- Factors effecting input-output ratio.

Based on the integration of the different thematic Layers in the GIS Domain the following Soil and water conservation measures were suggested based on the soil, slope, Drainage pattern and the present land use pattern for the study area.

\section{Conclusions}

The present project emphasizes on the power of GIS technology which will help the decision makers at block level to better understand and evaluate spatial data by creating graphic displays using information stored in the database. A GIS based infrastructure planning will help the government in planning, implementation and monitoring of various projects for development in different fields at much faster rate which in turn will make the state technologically more developed.

This analysis has confirmed the need for spatial planning, which can achieve the desired results of economic, social interaction and overall development of a region. This study involves a methodology for rank ordering the various settlements, so that, priorities for linking the settlements can be worked out.

This GIS database will be customized to meet the requirements of stake holder departments/concerned in providing the digital resource databases and any other requirements of the block, based on their problems/priority/ developmental programmes at Village/Block/Taluka level. The customized interface web application is shown in Figure 6 and Figure 7.

\section{References}

[1] Lakshmana Rao, M., (2003) Rural Infrastructure Planning with Emphasis on Road Network Connectivity by Coplanar Concurrent Theory, Map India, 2-4.

[2] Armstrong, J.H., Gross, M., Mullin, J.R. and Yaro, R.D. (2006) Infrastructures Planning in Rural Massachusetts, 1222.

[3] Chitale, V. and Vinayak Rao, M. (2006) An Approach for Planning Rural Road Connectivity to Habitations under PMGSY, 8-10.

[4] Bazlington, C. (2002) Geographical Information Systems and Housing Needs, 4.

[5] Groundwater Prospects Mapping Using Remote Sensing and GIS (Manual) by NRSA, 2008. 
Scientific Research Publishing (SCIRP) is one of the largest Open Access journal publishers. It is currently publishing more than 200 open access, online, peer-reviewed journals covering a wide range of academic disciplines. SCIRP serves the worldwide academic communities and contributes to the progress and application of science with its publication.

Other selected journals from SCIRP are listed as below. Submit your manuscript to us via either submit@scirp.org or Online Submission Portal.
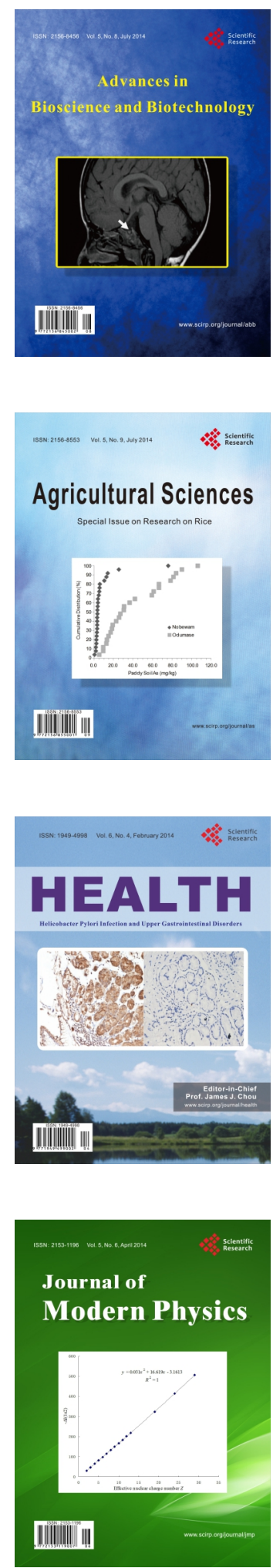
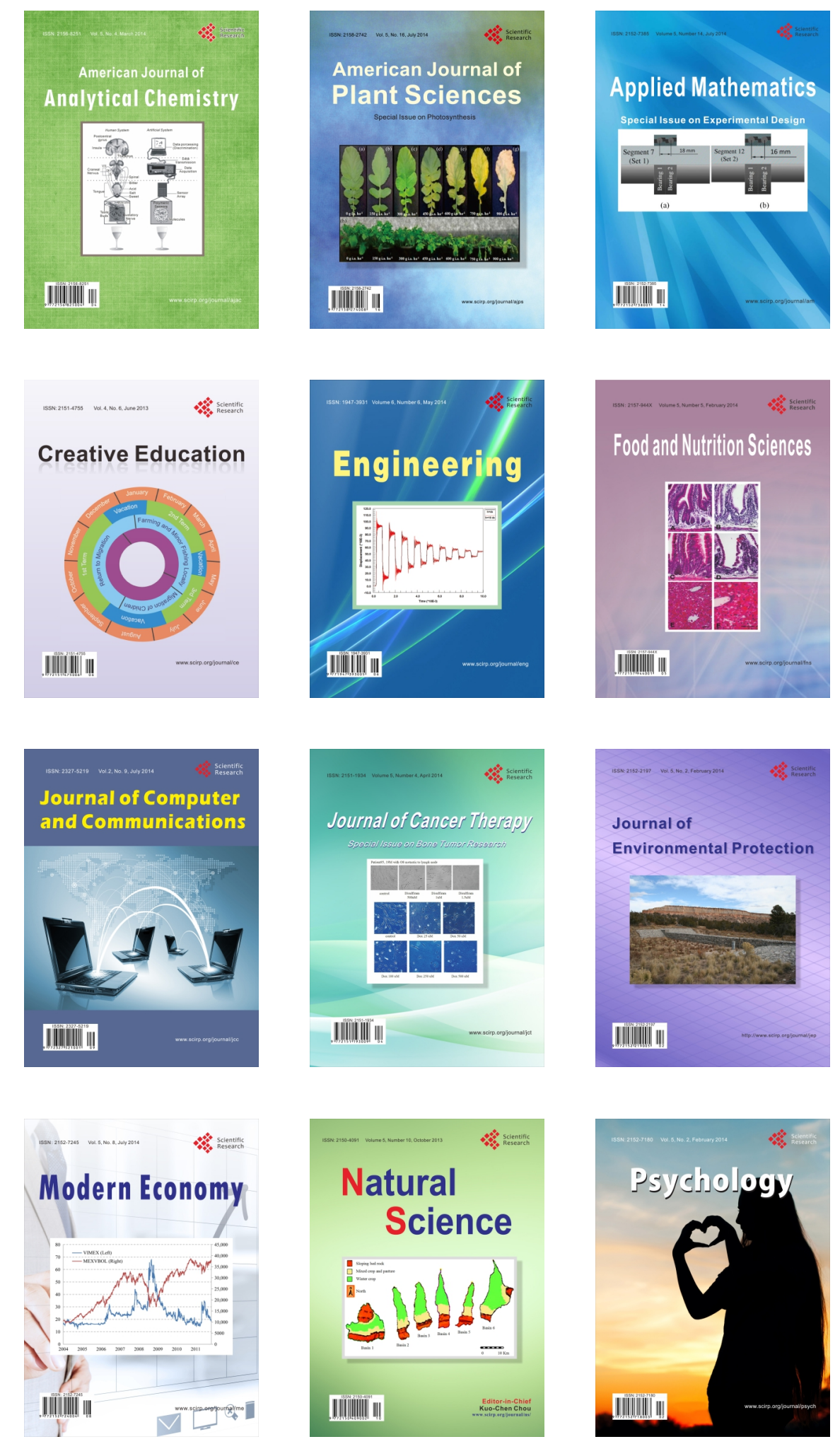